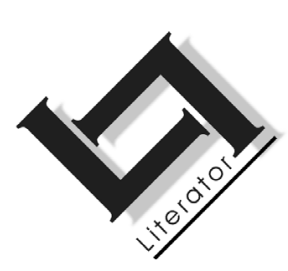

\title{
Keeping it in the family: incest, repression and the fear of the hybrid in Reza de Wet's English plays ${ }^{1}$
}

\author{
A. Krueger \\ Department of Drama \\ Rhodes University \\ GRAHAMSTOWN \\ E-mail: mnrkrueger@gmail.com
}

\begin{abstract}
Keeping it in the family: incest, repression and the fear of the hybrid in Reza de Wet's English plays

Reza de Wet has more than once referred in interviews to the syncretic relationship she sees as existing in the "long history" between Afrikaner and black cultures. Due to its close association with black African cultures, she claims that Afrikaner culture has fused a belief in mythologies and "magical thinking" with a "European consciousness" (Solberg, 2003:180). This article investigates ways in which some of De Wet's English translations - as well as her play "Concealment" (De Wet, 2004) demonstrate the consequences of a fear of this amalgamation; a dread of hybridity. Concurrent with this anxiety is the danger inherent in a repression of desire. In a number of De Wet's plays it seems that what is cloistered and protected within the purity of family (possibly a metaphor for the Afrikaner people) conceals an incestuous perversion.
\end{abstract}

1 This article is adapted from a chapter in the book Experiments in freedom: explorations of identity in recent South African English play texts which is due for release in early 2010 from Cambridge Scholars Press. 


\title{
Opsomming
}

\section{Binne die familie: repressie, bloedskande en die vrees vir hibriditeit in Reza de Wet se Engelse dramas}

\begin{abstract}
Reza de Wet het in meer as een onderhoud verwys na die sinkretiese verhouding wat sy sien in die "lang geskiedenis" tussen Afrikaner-en swart kulture. Sy beweer (Solberg, 2003:180) dat die Afrikanerkultuur mitologieë en magiese denkwyses van die Afrikakonteks met 'n "Europese bewussyn" geïntegreer het as gevolg van hierdie nabye assosiasie. Hierdie artikel ondersoek maniere waarin sommige van De Wet se dramas wat in Engels vertaal is - sowel as haar drama "Concealment" ["Versteking"] (De Wet, 2004) - die gevolge van 'n vrees vir hierdie samesmelting, 'n afsku in hibriditeit (of verbastering), demonstreer. Saam met hierdie angs, loop die inherente gevaar wat gepaard gaan met die onderdrukking van begeerte. In verskeie van $D e$ Wet se dramas lyk dit asof dít wat eenkant gehou en beskerm word binne die suiwerheid van die familie (moontlik'n metafoor vir Afrikaners) 'n bloedskandelike perversie versteek.
\end{abstract}

\section{Introduction}

In an interview with Rolf Solberg, Reza de Wet mercilessly dissects the work of other South African playwrights finding most of them severely lacking. When questioned on the sort of direction she thinks South African theatre should be taking, she says that Brett Bailey might be "the man we are looking for", since he is able to take things from disparate cultures and transform them while "creating visual excitement" (Solberg, 2003:191). On the other hand, she deplores what she sees as the sterile tradition of English theatre in South Africa (Solberg, 2003:190). She says that she does not "resonate at all with white South African theatre", since it is "what Peter Brook called deadly theatre" (Solberg, 2003:189). 2 In some ways, De Wet's own plays share some of the ethos of Bailey's magical representations which delve into the spiritual world. She told Ashraf Jamal

2 In The empty space, Brook (1968) writes of four types of theatre: deadly, holy, rough, immediate. Out of these, the "deadly" - as the name suggests - is the worst: commercialised (Brook, 1968:9); prostituted (Brook, 1968:10). This sort of theatre involves embalmed classics (Brook, 1968:10); an imitation of "externals" (Brook, 1968:12); and the attempt to preserve performance as history (Brook, 1968:15). It uses tradition as a barrier to a "living theatre" (Brook, 1968:16) and is typified by a lack of trust between artists (Brook, 1968:18). It labours under "conditioned reflexes" (Brook, 1968:23) and incompetence (Brook, 1968:29). This is theatre which has not died, but which kills the ideals to which theatre might aspire. 
what she has against the tradition of realism, which she sees as prevalent in South African theatre:

Realism, which deals with psychological complexity, is described by Meyerhold as 'peeping-tom theatre' which has betrayed its aboriginal function. Since theatre - both in the East and the West and in an African context - has always evolved from ritual invocations of the unknowable, the 'truth' of theatre is still linked to magical thinking, to transformation, to exorcism, and to heightened states of consciousness, which in more recent times have been described as - and to a certain degree have been degraded by the term - fantasy. If ... fantasy has a direct link to the ecstatic function of theatre, then it must surely be clear how fantasy in this context can nourish and revitalize our theatre, which has become so radically impoverished by particularly political and social realism. Death to peeping-tom. (Jamal, 2000:205.)

De Wet's notion of theatre is that it should be not only more than entertainment, but also more than a means of conveying history. Instead of trying to mirror a social reality, theatre, for her, should concern itself rather with mysteries, rituals and "the unknowable". Whereas many South African playwrights try to create a sense of familiarity for their audiences in order to comment on their specific socio-political environment, De Wet's plays are known for transporting hers into unfamiliar terrain, for arousing a sense of the uncanny - for their element of Vervremdung. The movement towards "realism" in theatre at the turn of the twentieth century hoped to portray psychological complexities and avoid the oversimplification of the melodramas of the nineteenth century stage. And yet, De Wet sees the move towards "realism", ironically, as an oversimplification of psychic forces and subjective experiences which may be more accurately conveyed in terms of a mysterious mythic landscape.

\section{A syncretic cultural identity}

I would like to highlight a specific theme of De Wet's work, namely the depiction of the devastating effects of repression, and the paradoxical desire which the denial of the other arouses. De Wet positions herself from within the world of the Afrikaner, and yet emphasises the danger of trying to maintain an exclusive, isolationist cul- 
ture. Although she writes only about Afrikaners, ${ }^{3}$ she also acknowledges her debt to African folklore and mythology which, she claims, inform every Afrikaner experience. For example, being brought up by a black nanny was an experience common to many white Afrikaans children of her generation, and De Wet talks about her "black mother" who raised her, saying that

... for her the stories were not myths, they were true ... and for me they also existed, of course ... She made me realise there are many realities. More than meets the eye ... It depends on how you take it in, you see. You make it part of you, in which case it is unforgettable and it forms you utterly. (Solberg, 2003:183.)

De Wet goes on to describe a curious symbiosis which she sees as having developed between the Afrikaner and the black cultures of South Africa, an encounter which has already lead to richly syncretic amalgamations. She says that "there is a long history" preceding the current events in South Africa, particularly as concerns the Afrikaners, whom she describes as "really a kind of white tribe, not a nation". She goes on to say that Afrikaners have

... an understanding of a kind of myth, the magical thinking that has been integral to the black experience in Africa. But then tinged with, or mixed with, a more European consciousness. (Solberg, 2003:108.)

Talk of an Afrikaans identity arising out of this kind of mixture is a radical departure from the identity mooted by Hendrik Verwoerd 4 who encouraged a view of the Afrikaner's history in Africa as having taken place in isolation from other cultural influences. It was under Verwoerd that, what has come to be referred to as a laager mentality, developed. 5 The laager is also a fitting metaphor for Ver-

3 De Wet's (2005:17) English scripts routinely advise that her characters "are not English-speaking South Africans, but Afrikaners and as such a 'South African' accent is not required".

4 It would be erroneous to claim that all Afrikaners agreed with Verwoerd, and yet his was an undeniably popular and powerful perspective at the time.

$5 \quad$ According to Purkett and Burgess (2002:231)

In the 1960s, the ruling Afrikaner nationalist elite developed a 'laager' (or 'circle of wagons') complex, especially under President Verwoerd. This complex led Afrikaner nationalists to see themselves as an ethnic and religious minority and as 'God's chosen people', surrounded by 'black heathens' and 'godless communists' and betrayed by the West. 
woerd's policy of Separate Development. This term implies that a trajectory of development can be described as unrelated to that occurring in neighbouring cultures; which seems a rather absurd way of describing the 300 odd years during which the Afrikaner people developed their culture and language within Africa. Hofmeyr (1987:95) writes that it is incorrect to assume that the Afrikaners have ever been a "monolithic volk". She makes the claim that the notion of a unified Afrikaner people was in many ways an artificial construction encouraged by the deliberate creation of a nationalising Afrikaner literature and writes that as late as the 1900s some multiracial communities of Afrikaner people could be found (Hofmeyr, 1987:101). It is interesting that an emphasis on Afrikaner literature in the Second Language Movement lead to ideals of exclusivity which later contributed to violent racism, whereas, for example, Giliomee (2003:xiv) refers to the original creation of Afrikaans as "one of the genuinely multi-racial achievements" of South Africa. Seeing syncretic fusions between Afrikaner and black cultures seems to be a more accurate perspective than one which considers either culture as a "separate development". 6 In terms of this view, 40 years of apartheid become a misinterpretation, a kind of illusionary gloss of reality as ideals of racial purity inevitably are.

Although De Wet is certainly indebted to a European literary tradition, one of the things which her earlier works do is to describe the insistence on cultural and ethnic purity as a kind of perversity. In many ways her works have been divisive and her induction into the canon of Afrikaans literature 7 has, then, created the exact opposite effect of that hoped for by Gustav Preller a century earlier, who tried to unite Afrikaners by means of a common literature.

\section{Translations of three early Afrikaans works}

I would like to begin this analysis of De Wet's texts by referring to a few of her early Afrikaans plays before moving to a fuller analysis of the postapartheid English work Concealment. Diepe grond (published in 1986, later translated as African gothic in 2005) ${ }^{8}$ was her

6 This is, of course, not to deny the unequal power relations between these different cultures.

7 She has won the highest accolade in Afrikaans letters, the Hertzog Price, twice.

8 The book jacket of the translation provides the following summary (De Wet, 2005): 
first play, and it won the ATKV9 award in 1985. The play provided a stinging critique of the notion of stable Afrikaner identity by portraying two incestuous children who respond to years of Calvinistic repression by murdering their parents. It was initially written as a parody of Alba Bouwer's Stories van Rivierplaas (1957), an idyllic Afrikaans pastoral novel and the characters originally had the same names as the Bouwer characters (Alie, Hennie, Ou-Melitie), however, after strong protest by Bouwer these names were changed to Sussie, Frikkie and Alina.

One is never sure exactly what the relation is between Sussie and Frikkie. 10 Part of what created such a stir, was the degree to which familiar identity structures, such as the traditional boere family on the farm, were subverted. Lewis (2000:2) describes the play as "a critical re-examination of Afrikaner myth and mentality ... an incestuous, confined parody of '30s Afrikaans drama aimed at forging a national identity". In a sense, this kind of instability and transgressive uncertainty harks back to the very early days of western theatre which Duncan (2006:217) describes in Performance and identity in the classical world:

As seen in all of these spectacles, it was the line between mimesis and reality that fascinated audiences ... There was a frisson, a thrill of transgression, perhaps even danger, in blurring or crossing this line.

\footnotetext{
A farm lies in ruins. And with mother and father now gone, a brother and sister face eviction by an officious lawyer. Abandoned, they endlessly enact the rituals of punishment once visited upon them by their parents. Widely regarded as a milestone in South African theatre, the play African Gothic tells the story of their final danse macabre. Despite overwhelming critical acclaim, it was also fiercely condemned by Afrikaans conservatives as being a subversive portrayal of repression.
}

Afrikaanse Taal- en Kultuurvereniging (Afrikaans Language and Cultural Association).

Shaner, who reviewed a London run of the play, introduces the siblings as follows:

This is a strange pair, whose weirdly disturbing relationship keeps the first act on its mystified toes. Are they, or are they not lovers? Are they, or are they not siblings? Are they, or are they not, stunted adults with white-trashy, morally and ethically deficient standards? (Shaner, 2005:16.) 
In a similar way, De Wet's play mixes familiar elements of folkish fiction, ${ }^{11}$ and yet, at the same time, arouses disconcerting suspicions that everything is not as it appears to be; that dark currents underscore perceptions of idyllic domesticity. It is as though forces at play in the unconscious are breaking through into the terrain dominated by the surveillance of the conscious mind. Prominent among these undercurrents is a vein of erotic desire, heightened by years of suppression. Sussie has been taught to believe that, because Grovés wife has "red nails and a red mouth", she is "bad", since her mother has told her that "women who want to improve on God's work are wicked and damned" (De Wet, 2005:34). It is this repression which eventually erupts into parricide.

Op dees aarde (1991) was the second of De Wet's plays, and she later translated it as Good heavens (De Wet, 2005). ${ }^{12}$ Here, we again encounter a strictly Calvinist, Afrikaans family whose insular world leads to the emergence of psychotic phenomena. The family is constantly worried about ways in which the community will categorise and judge them due to a previous indiscretion. They have been cast out by a church community, and fear that their every action is being evaluated by a vigilant and merciless God who stands ever-ready to punish them. As in Diepe grond, the greatest sense of guilt (and the consequent fear aroused by this guilt) is created by the threat of carnality. Similar to the society portrayed in Hawthorne's The scarlet letter (1850), this puritanical community believes that being swept away by a Don Juan or a charlatan, constitutes the greatest disgrace from which not even death will be able to liberate one.

In Op dees aarde (De Wet, 1991), the girl who has fallen into the murky trough of desire is Baby, the apple of her mother's eye. In sharp contrast to her, two spinster sisters remain bitter after years of neglect. By dying, Baby manages to stay young and charming, and

11 Hofmeyr (1987:111) writes that part of the Afrikaner nationalist movement involved the creation of a volkskunde, involving the collecting of "songs, antiques ... history and folklore". De Wet's works are peppered with Afrikaans idioms, sayings, myths. Breathing in (2004), for example contains numerous references to folk remedies (boererate).

The book jacket of the translation provides the following summary:

Good Heavens is a comedy thriller with the dark poetic heart of a folktale. Two spinster sisters, with their ailing mother and simple-minded brother, await the annual visit of their youngest sister. Deeply envious of her beauty and youth, they hatch a diabolical plot to rid themselves of her forever. (De Wet, 2005.) 
her beautiful ghost haunts the two sisters who have by then become crones. The sisters still want the spirit of Baby to repent, to admit to her lust, but she refuses. There is in some way a sense that Baby is part of her mother's dream, since, when her mother dies, she disappears. And yet, Baby eventually returns to deal with the will and the two wicked sisters are cast out, which also implies an indictment against other sins, such as pride and self-righteousness.

As with all of De Wet's plays there is a sense of foreboding throughout, a tone of disharmony, a subtle unease. The play delves into the ghosts and secrets of the Afrikaner past. An overbearing demand for privacy masks the fear of disgrace and the constant awareness of shame, which permeates the family's relationships. This creates an insular existence shielded from exchanges with the outside world. It is fitting that the family are undertakers, since they are kept busy burying the secrets of their past, which could equally be read as a metaphor of the Afrikaner past. There are skeletons in the cupboard and secrets which will never be revealed. For example, we never learn how Baby died. The long shadows of the past which haunt the family have been created by a fundamentalistic dogma and have been sustained by guilt; and the family suffers under the burden of maintaining this repression.

De Wet initially translated her third play, Drif (1993), as The crossing (2000) when it was first published in Graver's Drama for a new South Africa (1999). She later simplified this title to Crossing when it appeared in the anthology Plays one (2000).13 Lewis (2000:2) describes the play as subverting the "stolid national-familial Afrikaans drama of the 1930s". He also describes the play as "actively participating in forming the drama for a new South Africa (not 'from' or 'of') by reclaiming and popularizing hidden histories" (Lewis, 2000: 1). Similar to her previous work, Crossing (De Wet, 2000) creates a world comprised of a strange alternative reality which makes it impossible for an audience to draw on ready-made political or socio-

13 On the other hand, removing the article from the title is not necessarily a simplification, since it opens the title up to greater ambiguity. In brief, the plot of this play concerns two sister (Hermien and Sussie) who live next to a dangerous river. They offer travellers shelter, warning them of trying to cross the river when the water level has risen too high. They also bury the bodies of travellers who have drowned in the river, since the ghosts of travellers who have not been buried return to haunt them. A travelling hypnotist, Maestro, and his assistant Esmerelda, drowned in the river twenty years before the action takes place. Esmerelda's spirit has been haunting the sisters, who hold a séance in order to try to appease her restless soul. 
sexual definitions when trying to come to terms with the identities of the characters portrayed. Neither the strange power relation between Frikkie and Sussie (in African gothic; De Wet, 2005), nor the mysterious Svengalian connection between Maestro and Esmerelda (in Crossing; De Wet, 2000), are ever entirely clarified. The rules of the game are not always known. Again, as in her two earlier plays, there is the possibility here that a primordial desire suppressed by the forefathers has lead to a psychic quagmire from which a younger generation are attempting to extricate themselves.

Each of these early plays can also be read as indictments of patriarchy. In Op dees aarde, the absent husband and the charlatan have abandoned the women, and in Drif, Maestro is a hypocritical seducer. All three plays deal with the consequences of a heightened fear of impurity, a paranoia of the hybrid, a fear of intermingling. These plays show how an insistence on the purity of bloodline, lineage and culture creates a horror and consequent obsession with desire, which can lead to crippled, incestuous families.

\section{Concealment}

Concealment (De Wet, 2004) was originally written in English, and to my knowledge, has never been translated into Afrikaans. It is an excellent example of the themes which have already been highlighted in the earlier plays, such as the theme of suppressed feminine desire. ${ }^{14}$ More specifically, it deals explicitly with the colonial fear of the hybrid. Hybridity was at first a botanical and then a biological description which only later came to be applied to race (Young, 1995:6).15 The analogy made from animal husbandry was that it was through sexual contact that hybrid forms were created, and that these would produce inferior species, in the same way that the sterile mule was a hybrid of horse and donkey. Young (1995) explores a history of this suppression of sexuality between races in Colonial desire: hybridity in theory, culture and race, and comes to

14 Suppressed feminine desire is also dealt with overtly in De Wet's earlier play, Worm in the bud (1995).

15 One should bear in mind that at the turn of the century, in which the play is set, Afrikaners and English were considered to be two different races. This is pointed out by Jacobson (2007:18) in an essay on Kipling. The fact that English and Afrikaner are today easily conflated into a single racial category is an indication of how thinking along racial lines can change. It is, therefore, not impossible to imagine that in another hundred years, ostensibly "white" and "black" races might also be reduced to a single race. 
the conclusion that this sexual censorship often had the opposite effect of intensifying desire for the unknown other, a theme which drives Concealment.

In this play, a father arrives in a nameless African country which is more of a mythic place than an actual location. He has returned to fetch his daughter, May, whose husband, John, recently died of heat-stroke after having stepped out into the African wilderness without the protection of his hat. Instead of finding May in mourning, he discovers that she appears to be in good spirits, even though her appearance is unkempt. Her skin is changing colour, and according to her father, she is beginning to take on a distinctly local hue. When the father and Amy (May's sister) first see May, the father does not recognise her, and when Amy insists that it is his daughter, he says, "Don't be ridiculous. That woman is completely dishevelled. And she doesn't have a complexion. She must be a half-breed at least." (De Wet, 2004:306.)

When her identity is confirmed, he stares "in horror" at what has become of his daughter. It appears that she is being assimilated into the African climate which is associated with heat, dryness and colour; in contrast to Europe, which is depicted as cold and damp. As the play progresses, the audience discovers that there is a sexual association between May and the black gardener Samuel. Also, Amy discovers John's hat among May's "underclothes", lending credibility to the idea that, in collusion with the African sun, she is responsible for his death by withholding this protection and hiding it in the one place he would not look for it. The idea that he would not search the drawer where she keeps her underwear might also indicate his lack of interest in her sexuality.

Amy and May are anagrams of each other, and yet they each come to represent very different aspects of femininity. Perhaps, as the word May also indicates, she has a permissiveness denied to the constrained Amy. They are further distinguished in terms of their character descriptions, and in particular, with reference to their hair, a potent trope of sexuality. Whereas Amy's hair is "worn in a bun", May's "long, abundant hair is loosely tied back". Also, whereas Amy is characterised by her "large, luminous eyes", May is described in terms of her skin, which is "rich, golden brown from the sun" (De Wet, 2004:302). Similarly, Europe is associated with the cool, aloof, distant gaze, in contrast to the visceral description of May's body which, browned by the sun, has taken on the appearance of the hybrid, the half-caste. The sun provides an extended metaphor for acculturation to African conditions throughout the play. Dr Frost (the 
father) warns his girls that "the heat is enough to kill you" (De Wet, 2004:305). He also repeatedly warns them against exposing their bodies to the sun since this will damage their "fair skin" (De Wet, 2004:303). Elsewhere, he says to Amy, "you look quite pale" (De Wet, 2004:304) and warns her that "a young, pale-skinned woman is a terrible temptation!" (De Wet, 2004:336).

Throughout the play, the natural world, the outdoors, is contrasted with the interior world of the household. There is a similar sentiment in African gothic where the natural world is contrasted with domesticity. In that play Sussie says that flowers are not allowed indoors because she fears her mother's warning that "they bring germs into the house" (De Wet, 2005:30). In Concealment, it seems there is also a relation between colourful flowers and disease. The metaphor of a tended garden is taken further when Amy speaks to Samuel. She draws a parallel between the gardens of Europe and those of Africa, saying that in England they are "[n]eat and well tended. Everything in its place" (De Wet, 2004:315), and that flowers grow there which are "too fragile to survive here". When Samuel will not respond to Amy's flirtations she loses her temper, knowing that he speaks freely to May. Eventually, fuelled by jealousy and stoked into a righteous zeal by her father, Amy colludes with him in drugging May and carting her off back to England where she is to be incarcerated.

It is not only May's possible infringement of the laws of purity that condemn her, but also because she reveals what has remained repressed within the family history, namely that her father molested her when she was a little girl. Bringing this truth out into the light of consciousness becomes her chief crime. She recalls the carbolic smell of his hands:

I would be filled ... with a kind of ... horror ... and fear ... because I knew ... that you were coming up ... to say good night. That you would ... come and kiss me good night ... that you would ... touch ... my hair! (De Wet, 2004:334.)

This indictment of the moderation and restraint preached throughout by the father to his daughters is linked to his fear of the exotic. Themes which De Wet has reiterated in previous plays come to the fore here again, including the incestuous relationships of the colonisers who dread any mixing with the local population, perhaps for fear of humanising them. This is intensified by the fear of revelation; the fear of the exposure of repressed desire turns in on the family unit and sinks it into a quagmire of obsession and shame. The 
censoring of the desire for the other becomes a neurotic fascination. As Young (1995:xii) points out in Colonial desire,

Racial theory, which ostensibly seeks to keep races forever apart, transmutes into expressions of the clandestine, furtive forms of what can be called 'colonial desire': a covert but insistent obsession with transgressive, inter-racial sex, hybridity and miscegenation.

There is, thus, simultaneously, the fear of breaching the borders of one's identification and crossing over into unknown terrain, as well as the desire for exotic sexuality. This desire also creates fears within those in the colonial community who are associated with the person who has overstepped the mark. For example, Dr Frost feels threatened by the power which the invisible Samuel has over his daughter, since he wishes to keep her to himself. Young (1995:22) describes Bhabha's view that hybridity serves to unmask authority since it reverses structures of domination when knowledge which is denied is exchanged. There is also a threat that the concealed knowledge of the father's molestation of his daughter will be revealed. His greatest fear is that his daughter will have sex with the black gardener, and yet he considers his own sexual contact with his daughter as part of his means of civilising her, going so far as to refer to it as his "fondest ... most cherished memory" (De Wet, 2004:334). Whereas a healthy sexuality (which might mean crossing the line of identification between coloniser and colonised) represents a terrifying danger, Dr Frost appears to tolerate incest, since it keeps culture within the family circle. There is thus a metaphoric turnaround here, similar to the one described in African gothic: what is cloistered, nurtured, protected within the purity of family, has, by the end of the play, become the hallmark of perversity.

In the incestuous relations between the inheritors of the family farm in Diepe grond there is a sense that Afrikaner culture is insular, mistrusting of outsiders, and that this desperate desire for purity can become a vicious obsession. This obsession must then also be hidden. In Good heavens, Sophie rebuffs the concern of her neighbour by saying "a wound ... is a private matter" (De Wet, 2005:85). And Minnie says, "everywhere there are townspeople who whisper behind their hands and who look at us over their shoulders" (De Wet, 2005:87), while the mother talks of "watchful eyes" (De Wet, 2005:97) who won't leave them alone. Sophie is afraid of the people coming out of church, because "what will they think?" (De Wet, 2005:103). In this fear of exposure, the cycle of repression and suppression is maintained. 


\section{Conclusion: transforming repression}

Marthinus Basson, one of the most innovative theatre directors working today, has directed almost all of De Wet's plays in South Africa. He (Basson, 2005:10) says that

Reza de Wet's plays can seem quite simple and straightforward and could easily be grouped under labels like Fairy-tale, Magic Realism or Postmodern, yet they are unique in many ways and very, very deceptive, in the same way that the reflection of the sky in a pond with floating leaves is a pleasant illusion, masking a rich soup of rotting vegetation or worse.

Perhaps I have over-simplified De Wet's plays by writing that they are indictments against patriarchy and repression, as if there is a moral lesson to be learnt from reading them. And yet, I do believe that change and transformation form part of what she sees as the significance of theatre. She agrees that her plays have been described as "Magical Realism, with gothic elements, or dark elements", though she qualifies this by saying that she is interested in

... the re-enchantment of theatre, which has become ... very pedantic in most countries ... the magical theatre is the opposite: it creates! Theatre is a place of transformation, and a crucible of mysterious forces. (Solberg, 2003:178-179.)

I have theorised the hybrid as a possible good, however, this is perhaps also a simplification, since it is difficult to pinpoint exactly what De Wet might posit as a good. She has spoken of her refusal to overtly participate in political or gendered discourses 16 before, and, for her, the most important thing about writing after 1994 is that "[t]here is now a sense of more creative freedom" (De Wet et al., 1995:95). In some way her work is about liberation from repression since she sees fantasy, a category with which she repeatedly associates her work, as "a primary way of expressing repression in

16 When she was asked whether changes in the South African political situation have influenced her writing, she said: "I have not been aware of the need to write politically. My work has always been personal, so it has not affected me greatly." (De Wet et al., 1995:95.) She refuses to propagate specific political ends in her plays, saying that she writes "out of a purely personal impulse" (De Wet, 1995:90). Also, she consistently rejects any feminist agenda, and does not promote gendered readings of her work:

I don't agree with categorising people. It falls into the patriarchal trap of needing to define and separate. If you accept divisions then you are accepting those structures. I believe to become psychically androgynous is the answer. (De Wet et al., 1995:90.) 
society" (De Wet, 1995:91). In this there are ties to Jung's conception of the shadow ${ }^{17}$ a theory which provides a useful vocabulary with which to approach issues of South African postapartheid theatre. 18 The interesting thing about Jung's construction is that although the conscious mind is perceived as being in control, it is actually the forces bubbling up from the unconscious that hold the real power. One might say that the real identity in this case, as a cause of action and behaviour, is not the conscious, analytical mind. What this means is that those with firmly established shadows are not who they think they are. As Hall (1997:4) puts it:

[Y]ou can't map the unconscious because you don't know it. But you sort of know it when it erupts on you, when it sneaks up from behind you and hits you over the head. That's when you know that something has been repressed. It keeps on coming back, disturbing your discourse from underneath.

The shadow is an intensely personal construction, and yet, it can also apply to groups. The system of apartheid provides an example of the ideal conditions in which a collective shadow flourishes. The shadow aspect of a collective white psyche may have developed within the attempt to consistently relocate, hide, and deny access to black populations. There has thus been an urgent necessity for the integration of this shadow side. As De Wet et al. (1995:94) say, "if you repress something it will shatter you. Any deep repression that is never faced will destroy you". Her plays, then, can be read as ways of permitting access to unconscious material, of allowing what has been repressed back into consciousness, whether this is something out of one's past which one considers to be destructive, or whether it is a positive aspect of one's identity which has never been acknowledged.

It seems that De Wet is consciously working with elements which attempt to free the mind from its repressions. For example, she says of Crossing: "hopefully the structures of the play are liberating" (De

17 Though De Wet does not specifically refer to Jung's notion of shadow, she does mention her indebtedness to Jung (De Wet, 1995:94) and mentions the benefit she received from undergoing Jungian analysis.

18 The shadow consists of all the elements within the personality, both positive and negative, which a person deems to be unacceptable. It might also have been possible here to refer to Freudian accounts of the eruption of the id which occurs during the "return of the repressed"; but I will limit my discussion here to Jung's terminology for the sake of brevity. 
Wet et al., 1995:94). So there is an element of integrating repressed desire as well as, I believe, accepting the inherent hybridity of the Afrikaner culture. Most crucially, her analysis of Afrikaans culture relies on accepting its debt to both an European and an African consciousness, and an understanding that "there is an exchange between these two cultures":

I can only speak from an Afrikaans point of view, how close the Afrikaners are brought up with the African experience or the black experience. It's very close, there's an enormous bond between these two 'tribes'. So I believe there is a new reality being created here. (Solberg, 2003:180.)

The double hope for integration with Africa, and liberation from the repressions created by a mind bent on exclusivity, sustains Reza de Wet's plays, many of which serve as warnings of the dangers inherent in the fervent desire for purity and the resistance to the syncretic. Instead of causing sterility, it seems that hybridity leads to new life. As Breyten Breytenbach (1998:183) puts it:

My language speaks of the loss of purity ... Afrikaans is the visible history and the on-going process not only of bastardisation, but also of metamorphosis.

\section{List of references}

BASSON, M. 2005. Introduction: Plays two by Reza de Wet. London: Oberon. BREYTENBACH, B. 1998. Dog heart. Cape Town: Human \& Rousseau.

BROOK, P. 1968. The empty space. New York: Avon.

DE WET, R. 1991. Vrystaat trilogie: Diepe grond; Op dees aarde; Nag, Generaal. Pretoria: HAUM.

DE WET, R. 1995. Worm in the bud. (In Hutchison, Y. \& Omotoso, K., eds. Open space: six contemporary plays from Africa. Cape Town: Kagiso. p. 1-30.)

DE WET, R. 2000. Plays one: Missing, Crossing, Miracle. London: Oberon.

DE WET, R. 2004. Concealment. South African theatre journal, 18:299-351.

DE WET, R. 2005. Plays two: African gothic, Good heavens, Breathing in. London: Oberon.

DE WET, R., HUISMANS, A. \& FINESTONE, J. 1995. Anja Huismans and Juanita Finestone talk to Reza de Wet. South African theatre journal, 9(1):89-95.

DUNCAN, A. 2006. Performance and identity in the classical world. Cambridge: Cambridge University Press.

GILIOMEE, H. 2003. The Afrikaners: biography of a people. Cape Town: Tafelberg.

GRAVER, D., ed. 1999. Drama for a New South Africa: seven plays. Bloomington: Indiana University Press.

HALL, S. 1997. Random thoughts provoked by the conference "Identities". Critical arts, 11(1):1-16. 
HAWTHORNE, N. 1990 [1850]. The scarlet letter. Oxford: Oxford University Press.

HOFMEYR, I. 1987. Building a nation from words: Afrikaans language, literature and ethnic identity, 1902-1924. (In Marks, S. \& Trapido, S., eds. The politics of race, class and nationalism in twentieth century South Africa. London: Longman. p. 95-123.)

JACOBSON, D. 2007. Kipling in South Africa. London review of books, 29(11):17-20.

JAMAL, A. 2000. Stagings. (In Nuttall, S. \& Michael, C.A., eds. Senses of culture: South African cultural studies. Cape Town: Oxford University Press. p. 197-211.)

LEWIS, S. 2000. Review of David Graver's Drama for a new South Africa. HAfrLitCine, HNet Reviews in the Humanities and Social Sciences, May. http://www. h-net.msu.edu/reviews/showrev.cgi?path=16569958503141> Date of access: 15 Aug. 2006.

PURKETT, H. \& BURGESS, S. 2002. South Africa's chemical and biological warfare programme: a historical and international perspective. Journal of Southern African studies, 28(2):229-253.

SHANER, M. 2005. African gothic at the Elephant Theatre. Back stage West, 12(5):16.

SOLBERG, R. 2003. South African theatre in the melting pot: trends and developments at the turn of the millennium. Grahamstown: Institute for the Study of English in Africa.

YOUNG, R. J.C. 1995. Colonial desire: hybridity in theory, culture and race. London: Routledge.

\title{
Key concepts:
}

\author{
Afrikaner \\ Concealment (play) \\ De Wet, Reza \\ hybridity \\ incest \\ Jung (shadow) \\ postapartheid literature \\ repression \\ theatre/drama, South African
}

Kernbegrippe:

\author{
Afrikaner \\ bloedskande \\ Concealment (drama) \\ De Wet, Reza \\ hibriditeit \\ Jung (skaduwee) \\ postapartheid letterkunde \\ repressie \\ teater/drama, Suid-Afrikaanse
}

